\title{
ARE RELIGIOUS CONSUMERS MORE ETHICAL AND LESS MACHIAVELLIAN? A SEGMENTATION STUDY OF MILLENNIALS
}

\begin{abstract}
Millennial consumers are increasingly becoming important actors in business that account for sufficient purchasing power. However, Millennials are infamously narcissistic and their views of ethics are more relaxed than previous generations (i.e. Baby Boomers, Generation X). Millennials remain poorly understood in general, especially in the context of developing countries. Hence, the purpose of this study was to profile this generation by segmenting Millennials in Indonesia and investigating differences between these segments on their ethical beliefs and Machiavellianism, an important personality characteristic. This study used a convenience sample from a university in Indonesia $(\mathrm{N}=540)$. The TwoStep cluster analysis produced three segments, namely, 'The Religious Millennials', 'The Lukewarm Religious Millennials' and 'The Least Religious Millennials'. Consumers who are highly religious are less likely to engage in various unethical behaviours. Interestingly, no significant differences were found between the Lukewarm Millennials and the Least Religious Millennials on their ethical beliefs. This research makes several research contributions. First, this study extended The Hunt-Vitell theory of ethics, where an individual (i.e. Millennials) confronts a problem perceived as having ethical content. Second, the study examined consumer ethics in the context of developing countries where religion plays a significant role in people's daily life. Third, through understanding different segments, the result assist educators, social marketers and public policy makers in creating an effective campaign to reduce unethical behaviour among Millennials.
\end{abstract}

Keywords: Consumer ethics, Machiavellian, Millennials, Segmentation, Indonesia

Paper type: Research paper 


\section{INTRODUCTION}

Millennials are young consumers, born between approximately 1980 and 2000 (Howe and Strauss 2009; McGlone et al. 2011). Millennials are increasingly becoming important actors in business and account for sufficient purchasing power, estimated at around US\$1.3 trillion in the US and around US\$10 trillion globally (Brown 2015). Moreover, Millennials are considered as the most powerful group in the marketplace and will continue to make significant impact on world economies (Bucic et al. 2012; Farris et al. 2002). This group will make up 75\% of the workforce by 2025 (Deloitte 2014; Pendergast 2007). However, Millennials are infamously more narcissistic than previous generations (Twenge et al. 2008; Westerman et al. 2011). Narcissism is defined by grandiose views of personal superiority, an inflated sense of entitlement, low empathy toward others, fantasies of personal greatness, a belief that ordinary people cannot understand one, and the like (American Psychiatric Association 1994). Narcissistic individuals often engage in a variety of unethical behaviour such as anger and self-enhancing attribution (Farwell and Wohlwend-Lloyd 1998) and derogation to those who provide threatening comments (Kernis and Sun 1994). Moreover, their views of ethics are more relaxed than the previous generations (Grabrini 2016). A report suggests that Millennials in Indonesia are particularly unique, as they display more nationalism, patriotism and xenophobic tendency than their predecessors (Generation X or the baby boomer) (Jakarta Post 2017). Moreover, Indonesian's Millennials increasingly show support towards religious conservatism and becoming more intolerant (McBeth 2018).

Studies have indicated that religiosity plays an important role in forming consumers' values and beliefs (Arli and Tjiptono 2014; Vitell and Paolillo 2003; Vitell et al. 2005). A few studies have explored ethical consumers among Millennials in both developed and developing countries, but failed to include religiosity in the analysis (e.g. Culiberg and Mihelič 2016; Bergman et al. 2013; Bucic et al. 2012; Perret and Holmlund 2013; Weber 
2017). In the context of developing countries, religion has always been an important part of people's lives (Arli and Tjiptono 2014; Eister 1964). A report shows that in 10 developing countries (i.e. Bangladesh, Niger, Yemen, Indonesia, Malawi, Sri Lanka, Somaliland religion, Djibouty, Mauritania and Burundi), $98 \%$ of respondent say that religion is important in their daily lives (Crabtree 2010). Moreover, Flurry and Swinberghe (2016) found that, among Millennials, family parenting style and parent's religiosity significantly reduced Millennials unethical behaviour.

Despite their size and importance (Diamandis 2015; Schawbel 2013), Millennials remain poorly understood in general (Phillips 2007; Bucic et al. 2012). In addition, the association between religion and ethical beliefs among Millennials remains inconclusive (Vitell et al. 2016; Yilmaz and Bahçekapili 2015). Religiosity can also improve a person's sense of well-being (Francis and Kaldor 2002; MacIlvaine et al. 2013), physical health such as decreasing tobacco and drug usage (Iannaccone 1992; Koenig et al. 1993) and altruistic behaviour such as a desire to volunteer in community-orientated activities (Brooks 2006; Gibson et al. 2008). As a consequence, an understanding of how religiosity relates to a potentially heterogeneous cohort of Millennials is essential when communicating the importance of being ethical and less narcissistic. Hence, the purpose of this study is to segment Millennials in Indonesia and to investigate differences between these segments on their ethical beliefs and Machiavellianism, an important personality characteristic relating to ethical beliefs (Al-Khatib et al. 2004; Rawwas et al. 1994).

In the context of Indonesia, the Millennials are uniquely different than their global counterpart. A report revealed that Millennials claimed that religion is the key to happiness (Heriyanto 2018). This is in contrast to the global trend where half of global youths believed that religions had a negative impact to the world (Varkey Foundation 2018). The Indonesian youth are more likely to show obedience to religion and display their religious lifestyle (e.g. 
wearing hijab) (Sarahtika and Yasmine 2018). Despite the rise of Islamic conservatism, not all Millennials embrace conservativism. This creates segments within the Indonesian' Millennials, being moderate versus fundamentalist Millennials (Hodge and Rayda 2018; Varagur 2017). Consequently, these segments show different views, with some of them leaning toward xenophobia, while others remain modern and outward looking (McBeth 2018).

This research will make several research contributions: First, this study extends the Hunt-Vitell theory of ethics. The theory suggests when an individual confronts a problem perceived as having ethical content, an individual's religiosity will influence his or her view of that situation (Hunt and Vitell 2006). Moreover, each individual also possess a certain degree of Machiavellianism. There are still limited empirical research incorporated the two constructs (i.e. religion and Machiavellianism). Tang and Tang (2010) found that religion is the strongest determinants of ethics while Machiavellianism is related to unethical behaviour, from a Judeo-Christian's perspective.

Furthermore, this study focuses on consumers from a non-highly religious non JudeoChristian society (i.e. Indonesia). Vitell (2009) suggests more studies outside the US are needed to uncover the role of religiosity on consumer ethics. Hence, this study will complement other studies using non-US cultures (i.e. Arli and Tjiptono 2014; Ahmed et al. 2003; Rawwas et al. 2006; Singhapakdi et al. 2000, Siu et al. 2000). Finally, through segmentation, the results of this study will inform public policy makers and educators in developing effective social marketing campaigns to reduce the Millennials' unethical behaviour. 


\section{LITERATURE REVIEW}

The study uses The Hunt-Vitell's $(1986 ; 2006)$ theory of ethics. The theory addressed the situation in which an individual confronts a situation perceived of posing an ethical dilemma. The theory proposes environments and personal characteristics as factors influencing an individual's perception of an ethical problem. Environments include cultural, professional, industry and organisational. Consequently, these factors become the lenses on how they perceive the alternatives and consequences of the ethical dilemma. This study focuses on religion as part of the cultural environment and Machiavellians as part of the personal characteristic (Vitell 2006). The two constructs combined have not been empirically examined as the contribution factors to ethical beliefs. Singhapakdi and Vitell (1990), exploring only Machiavellianism and ethics, found that marketers with a high Machiavellianism scale perceived ethical problems as less serious and were unlikely to view punishment of unethical behaviour as a viable alternative.

\subsection{Consumer ethics}

Muncy and Vitell (1992) defined consumer ethics as "the moral principles and standards that guide behaviour of individuals or groups as they obtain, use and dispose of goods and services" (p. 298). The concept of consumer ethics was derived from a general theory of marketing ethics (Hunt 1990; Hunt and Vitell, 1986; Vitell and Hunt 1990). The theory proposed that an individual will frequently confront a problem perceived as having ethical content. Once an individual perceives a situation as having ethical content, the individual will explore various alternatives to solve the problem (Vitell and Hunt 1990; Hunt and Vitell 2006). Subsequently, various studies indicated that the strength of religiosity resulted in differences in an individual's decision making processes when they faced by situations involving various ethical issues (Delener 1990; Green 1988; Wilkes et al. 1986). In response 
to this issue, Muncy and Vitell's (1992) developed the consumer ethics scale (CES) which has become the most widely used construct of consumer ethics (e.g. Arli and Tjiptono 2014; Arli, Leo, \& Tjiptono, 2016; Arli \& Pekerti 2016; Bonsu and Zwick 2007; Flurry and Swimberghe 2016; Swaidan 2012; Muncy and Vitell 1992; Vitell and Muncy 1992; Vitell et al. 2013).

Studies have investigated the contributing factors of consumers' ethical beliefs such as religion (Arli and Tjiptono 2014; Vitell 2009; Vitell et al. 2005); moral philosophy (Lu and Lu 2010); materialism (Muncy and Eastman 1998; Tang and Chen 2008; Vitell et al. 2006); gender (Bateman and Valentine 2010); acculturation (Pekerti and Arli 2017; Zwaidan et al. 2006; Zwaidan 2012); and personality trait (Rallapali et al. 1994). Nonetheless, there are still limited studies investigating the role of Machiavellianism on ethical beliefs.

Machiavellianism is related to unethical behaviour (Collins 2000; Jones and Kavanagh 1996). Individuals with high Machiavellianism are more likely to manipulate, win more, persuade others more and are often associated with antisocial behaviour (Geis and Chrisie 1970; Ross and Robertson 2003; Tang and Tang 2010; Singhapakdi and Vitell 1991). Hence, the next section will discuss the definition and the role of Machiavellianism on consumer ethics.

\subsection{Machiavellianism}

Machiavellianism was first coined by Christie and Geis (1970) as a personality trait. It is based entirely on convenience, manipulation, exploitation, and deviousness and is devoid of positive virtues such as trust, honour, and decency. Machiavellianism is the employment of cunning and intentional deceptiveness. It involves a relative lack of affect in interpersonal relationships, a lack of concern with conventional morality, a lack of gross psychopathology and low ideological commitment (Christie and Geis 1970). 
Hunt and Chonko (1984, p. 30), noted that "the label Machiavellianism [is] becoming a negative epithet, indicating at least an amoral (if not immoral) way of manipulating others to accomplish one's objectives”. Similarly, Dahling et al. (2009, p. 228) defined Machiavellianism as the desire to control as "a need to exercise dominance over interpersonal situations to minimise the extent to which others have power" and distrust of others as "a cynical look on the motivations and intentions of others with a concern for the negative implications that those intentions have for the self". Machiavellianism is a complex set of characteristics that may include several dimensions, such as amorality, desire to control and distrust of others (Christie and Geis 1970). People that exhibit these characteristics are also less likely to be ethically sensitive marketers (Singhapakdi 1993). In addition, there are various degrees of Machiavellianism between generations (Singhapakdi 1993). Moreover, Tang and Tang (2010) found that intrinsic religiosity is negatively related to Machiavellianism, hence positively related to unethical behaviour intentions.

\subsection{Religiosity}

MacDaniel and Burnett (1990) defined religiosity as a belief in God or Supreme Being followed by a commitment to follow rules and principles believed to be set by God. Moreover, Allport and Ross (1967) defined religious orientation as the extent to which a person lives out his or her religious beliefs. Religiosity is usually defined in terms of (1) cognition (religious knowledge, religious beliefs); (2) affect, which has to do with emotional attachment or emotional feelings about their religion; and/or (3) behaviour, such as frequencies of attendance to a religious service, Bible reading, and praying (Barnet et al. 1996; Cornwall et al. 1986). Studies indicate that religiosity is a stronger determinant of personal values than almost any other predictor, and that the level of religiosity would have a 
positive effect on an individual's standard of ethics (Huffman 1988; Giorgi and Marsh 1990; Vitell 2009).

Religious motivations can be viewed in terms of intrinsic and extrinsic religiosity. The extrinsically motivated person uses his or her religion, while an intrinsically motivated person lives his or her religion (Allport and Ross 1967; Kirkpatrick 1989). An individual with strong intrinsic religiosity tends to live daily life according to his or her religion. Extrinsic religiosity can be categorised into two constructs; extrinsic personal, where (1) an individual expect personal benefits from a religion such as peace and comfort; and (2) extrinsic social, where an individual expects a social benefit from a religion such as getting social support by joining a religious community (Kirkpatrick 1989). The intrinsic and extrinsic motivations are often not separate, but intertwined within an individual. Someone who has high intrinsic religiosity may exhibit higher extrinsic religiosity (Cohen et al. 2005; Pekerti and Arli 2017). Vitell (2009) concluded that there is a significant correlation between individuals' strength of religious beliefs and their attitude toward the ethicality of various questionable behaviours.

In the last few decades, studies have examined the influence of religion on an individual's ethical judgement, beliefs, and behaviour (e.g. Arli et al. 2016; Arli and Tjiptono 2014; Hunt and Vitell 1986, 1993; McNichols and Zimmerer 1985; Rashid and Ibrahim 2007; Rawwas 1996; Vitell and Paolillo 2003; Vitell et al. 2005, 2006). Most studies found that people with high intrinsic religiosity are less likely to engage in unethical behaviour (Arli and Tjiptono 2014; Huelsman et al. 2006; Longenecker et al. 2004; Vitell et al. 2006; RandophSeng and Nielsen 2007). In contrast, some studies indicated that extrinsic personal and social religiosity has no effect on unethical behaviour (Arli and Tjiptono 2014; Vitell et al. 2005). Based on various consumers' attitudes toward ethical behaviour, studies have attempted to segment these consumers (e.g. Al-Khatib et al. 2005; Arli and Pekerti 2016). The studies 
have concluded that companies should adapt their marketing strategies upon the segment being targeted. The next section will discuss the definition and importance of segmentation study.

\subsection{Segmentation}

Segmentation is based on the economic pricing theory and helps increase efficiency in both resource allocation and return on investment (Dibb et al. 2002). From a marketing perspective, Dickson and Ginter (1987, p. 4) defined marketing segmentation as "heterogeneity in demand functions exists such that marketing demand can be disaggregated into segments with distinct demand function”. Donovan, Egger and Francas (1999) suggest three key steps of market segmentation: (1) identifying homogenous segments within a larger heterogeneous population; (2) evaluating and selecting one or multiple segment(s); and

(3) developing a program suited to the unique needs and characteristics of the target $\operatorname{segment}(\mathrm{s})$.

The segmentation approach has been used extensively in various contexts (but not limited to): (1) ethical consumers- ecologically conscious consumers (Awad 2011; Bucic et al. 2012; Dansirichaisawat and Suwunnamek 2014; Straughan and Roberts 1999); and actionable and strategy yielding marketing variables (Al-Khatib et al. 2005); (2) tourismsenior pleasure travel (Shoemaker 1989); cycle tourism (Ritchie et al. 2010); nature-based tourism (Tkaczynski et al. 2015); and music festivals (Tkaczynski and Rundle-Thiele 2013); and (3) social marketing - physical activity (Boslaugh et al. 2005; Schuster et al. 2015); and alcohol consumption (Dietrich et al. 2015). It is universally acknowledged within the literature that there is no best way to segment customers (e.g. Kotler 1988). Respondents can be segmented a priori where the researcher defines the basis for segmenting the market from the outset (i.e. based on pre-existing demographic data such as age or social economic status), 
or posteriori, where the researcher defines the existing segments once the data has been collected (Dolnicar 2004). The posteriori segmentation approach is recommended when the number, size and structures of sub-markets is unknown, and consequently, multivariate analysis (i.e. factor analysis, cluster analysis) is usually employed to profile consumers into segments.

Researchers can employ demographic, geographic, psychographic and/or behavioural bases to profile consumers into specific segments based on key criterion (Kotler 1988). Segmentation based on a single base may not be representative of a diverse and heterogeneous group (Bowen 1998). Findings indicate that, despite a significant amount of past research attention, demographic criteria are not adequate as a profiling method compared to psychographic criteria (Dietrich et al. 2015; Straughan and Roberts 1999). For example, people in the same demographic group can have very different psychographic profiles (March and Woodside 2005). At the same time, segmenting exclusively on psychographics can be difficult for marketing purposes, as the accessibility of these markets can be difficult to identify without known demographics such as age or nationality (Kolb 2006). As a consequence, combining descriptive variables (e.g. demographics) with predictive variables (e.g. psychographic and behavioural) provides a clearer insight into marketing and communications strategy formulation (Murphy and Murphy 2004). This research will use a combined segmentation approach to investigate differences between each religious segment. In conclusion, through segmentation, this study aim to address two research questions: (1) through segmentation, what are the effect of consumers' religiosity on their perception toward ethical behaviour and Machiavellianism? and (2) what are the demographic profiles of each religious segments? As previously mentioned, the study will examine differences between segments on their ethical beliefs and Machiavellianism. Hence, the purpose of this study is to segment Millennials in Indonesia and investigate differences between these 
segments on their ethical beliefs and Machiavellianism, an important personality

characteristic relating to ethical beliefs (Al-Khatib et al. 2004; Rawwas et al. 1994). Finally, based on the previous discussions, we propose the following hypothesis:

H1: Religious segments are more likely to be sensitive toward various ethical issues compared to the less religious segments among Millennials in Indonesia.

H2: Religious segments are more likely to have lower Machiavellianism beliefs compared to the less religious segments among Millennials in Indonesia. 


\section{METHODOLOGY}

\subsection{Research Context}

The study used a convenience sample from a large private university in Surabaya, Indonesia. Indonesia is the fourth most populous nations in the world, with around 255 million people (Central Intelligence Agency 2015). Indonesia is a country of cultural diversity and home to the largest Muslim population in the world, with $88 \%$ of the population, followed by $8 \%$ Christian/Catholic, $2 \%$ Hindu, $1 \%$ Buddhist, and 1\% other. It is considered as one of the most religious countries, with more than $90 \%$ of the people of this country considering religion to be an important factor in their daily lives (World Atlas 2016). More importantly, Indonesia's population is relatively young; in 2012, it was estimated that $50 \%$ of the Indonesian population of 243 million is under 25 years old and $27 \%$ are under 15 (Population Reference Bureau 2012). Finally, Indonesia is also the largest economy in Southeast Asia with the Gross Domestic Product (GDP) per capita of US\$11,100 in 2015 (Central Intelligence Agency 2015).

\subsection{Data Collection}

The researchers distributed 600 questionnaires to students in their classrooms. All students are from the Faculty of Business and Economics at a large private University in Surabaya, Indonesia. The survey was first translated to Indonesian, whereby a professor of linguistics read the translation and discussed any discrepancies with the translator until a consensus was reached. Participants returned 576 questionnaires, yielding a response rate of $96 \%$. Incomplete questionnaires with too many missing values were removed, which resulted in 540 questionnaires, yielding an overall response rate of $90 \%$. The demographic profile of respondents indicated that there were more female than male respondents $(67 \%$ and $33 \%$, respectively), most were single (92\%), 83\% were between the ages of 18 and 20 years, and 
$14 \%$ were between the ages of 21 and 23 years. Finally, 36.5\% were Muslim, 50.9\% were Christian/Catholic, 9.1\% were Buddhism, $2 \%$ were Hinduism and 1.5\% were others.

\subsection{Measures and Reliability}

\subsubsection{Consumer ethics scale}

Consumer ethics were measured using the updated CES (Vitell and Muncy 2005). The scale examines consumers' ethical beliefs regarding various questionable behaviours based on the ethicality of the behaviour. The scale consists of four dimensions. First, actively benefiting from illegal activities (ACTIVE). This is where the behaviour can be considered as breaking the law. For example, drinking a can of soda in a supermarket without paying for it. Second, passively benefiting (PASSIVE). This is a situation where consumers are passively receiving the benefit due to others' mistake. For example, knowing that he/she is receiving too much change from a waiter and not saying anything. Third, actively benefiting from deceptive (or questionable, but legal) practices (QUESTIONABLE). This is a behaviour where it is unethical to do so, but there are no legal consequences. For example, returning merchandise to a store by claiming it was a gift when it was not. Fourth, no harm/no foul activities (NO HARM). This is a behaviour where there is minimal to no legal consequence. For example, an individual is spending over an hour trying on different dresses and not purchasing any (Vitell and Muncy 2005). Most consumers reported it was more unethical to benefit from an active/illegal activity than passively benefiting activity (Arli and Tjiptono 2014; Vitell and Paollillo 2003). In addition, consumers noted that benefiting from a passive activity was more unethical than benefiting from questionable but legal activities. Furthermore, the perception of no harm/no foul involvement was generally acceptable and considered more ethical than the previous three ethical beliefs (Vitell and Paolillo 2003). The reliability of the four dimensions on the CES was as follows: ACTIVE (4 items, $\alpha=0.626$ ); PASSIVE (3 
items, $\alpha=0.730$ ); QUEST (5 items, $\alpha=0.745$ ); and NO HARM (3 items, $\alpha=0.660$ ).

Respondents rated each behaviour on a 5-point Likert-type scale ranging from $1=$ strongly

disagree to $5=$ strongly agree. A high score (e.g. 4 or 5) indicated that consumers consider a particular action as more acceptable or ethical.

\subsubsection{Religiosity scale}

An individual's religiosity was measured by the revised intrinsic, extrinsic personal and extrinsic social religiosity scales adapted from Allport and Ross (1967) by Kirkpatrick (1988) and Vitell et al (2005). The reliability of the religiosity dimensions was as follows:

INTRINSIC ( 6 items, $\alpha=0.865$ ); EXTRINSIC PERSONAL RELIGIOSITY ( 3 items, $\alpha=$ 0.796); and EXTRINSIC SOCIAL RELIGIOSITY ( 3 items, $\alpha=0.862$ ). Two items with lower loading scores were removed. Respondents rated each behaviour on a 5-point Likerttype scale, ranging from $1=$ strongly disagree to $5=$ strongly agree. A high score indicated that individuals had high intrinsic, extrinsic personal and extrinsic social religiosity. Moreover, perceived religiosity was measured using the single item: 'how religious would you say you are?' (1=not at all religious; $10=$ very religious $)$. A high score specified high perceived religiosity.

\subsubsection{Machiavellianism scale}

Machiavellianism was measured using scale items developed by Dahling et al. (2008) which measured three personality traits: amorality, control over others, and distrust of others. The reliability of the three dimensions was as follows: AMORALITY (4 items, $\alpha=793$ ); DESIRE FOR CONTROL ( 3 items, $\alpha=0.830$ ) and DISTRUST OF OTHERS ( 5 items, $\alpha=$ 0.792). Respondents rated each behaviour on a 5-point Likert-type scale, ranging from $1=$ strongly disagree to $5=$ strongly agree. The complete list of scale items are listed in Table 1 . 


\subsection{Data Analysis}

In employing a posteriori segmentation approach (Dolnicar 2004), a TwoStep cluster analysis was conducted using baseline psychographic measures (intrinsic, extrinsic personal, extrinsic social and religiosity). The analysis produced a sample $(\mathrm{N}=540)$ with a silhouette measure of cohesion and separation of 0.3 . A silhouette of more than 0.0 is needed for the within-cluster distance and the between cluster distance to be valid (Norušis 2011). A cross-validating method of the identified segment was carried out by dividing the total sample $(\mathrm{N}=540)$ in half and repeating the identical analysis on each half the sample (Punj and Steward 1983). A three segment solution with a total of four segmentation variables (i.e. intrinsic, extrinsic personal, extrinsic social and religiosity) was accepted as the final solution. Then, variables individual predictor importance scores (ranging from 0 least important to 1 most important) were assessed. The most distinguishing factor was intrinsic religiosity (1.0), followed by extrinsic personal religiosity (0.88), self-perception of religiosity (0.40) and extrinsic social religiosity (0.27).

The analysis produced three segments namely, 'The Religious Millennials', 'The Lukewarm Religious Millennials' and 'The Least Religious Millennials' (see Tables 2 and 3). Subsequently, using cross-tabulation, we explored the profile of each segment based on their religious activities found within the literature such as frequencies of attending a worship service (Arano and Blair 2008; Ford 2006) and their frequency of praying (Brown 2009; Francis and Kaldor 2002). Finally, using Analysis of Variance (ANOVA), we examined each segment's belief toward four unethical behavioural beliefs (i.e., actively benefiting, passively 
benefiting, questionable behaviour, and no harm) and their perception toward three Machiavellianism constructs (i.e., amorality, desire for control, and distrust of others).

The first segment (The Religious Millennials) comprised 36.9\% of respondents. Within this segment, $18.2 \%$ attend a worship service more than once a week, $26.3 \%$ attend a worship service once a week and $34.8 \%$ attend a worship service once a month. There are more females $(76.8 \%)$ than males $(23.2 \%)$. The second segment (The Lukewarm Religious Millennials) is the largest segment, consisting of $38.8 \%$ of respondents. Only $5.7 \%$ of this segment attends a worship service more than once a week, 20.2\% attends a worship service once week and $47.1 \%$ attend a worship service once a month. In this segment, there are also more females (65.4\%) than males (34.6\%). The last segment (The Least Religious Millennials) is the smallest segment, with $24.3 \%$ of respondents. Only $4.6 \%$ of this segment attends a worship service more than once a week, $13.8 \%$ attend a worship service once a week and $44.6 \%$ attend a worship service once a month. Interestingly, in this segment, the number of females (55.4\%) and males (43.8\%) are similar.

Overall, The Religious Millennials' segment has the highest number of people attending a worship service more than once a week (66.6\%), compared to $22 \%$ (The Lukewarm Millennials) and only 11.1\% (The Least Religious Millennials) of the other two segments. The results show significant differences between each segment on their frequencies of attending a worship service and praying.

\section{Insert Table 2 About Here}

In regards to consumer ethics, The Religious Millennials segment showed the most sensitivity to perceiving a potential ethical problem ${ }^{1}$. The study found significant differences

\footnotetext{
${ }^{1}$ We thank an anonymous reviewer for this feedback
} 
between The Religious Millennials and other two segments (i.e. The Lukewarm Millennials and The Least Religious Millennials) on their ethical beliefs. The mean values for this segment are as follows: $\mathrm{M}_{\mathrm{ACTIVE}}=1.75 ; \mathrm{M}_{\mathrm{PASSIVE}}=1.74 ; \mathrm{M}_{\mathrm{QUEST}}=2.10 ;$ and $\mathrm{M}_{\mathrm{NOHARM}}=2.87$ $(p<0.05)$. Interestingly, there are no significant differences between The Lukewarm Religious segment (i.e. $\mathrm{M}_{\mathrm{ACTIVE}}=2.02 ; \mathrm{M}_{\mathrm{PASSIVE}}=2.19 ; \mathrm{M}_{\mathrm{QUEST}}=2.41$; and $\mathrm{M}_{\mathrm{NOHARM}}=$ 3.26; $p>0.05$ ) and The Least Religious segment (i.e. $\mathrm{M}_{\mathrm{ACTIVE}}=2.00 ; \mathrm{M}_{\mathrm{PASSIVE}}=2.18$; $\mathrm{M}_{\mathrm{QUEST}}=2.48$; and $\left.\mathrm{M}_{\mathrm{NOHARM}}=3.31 ; p>0.05\right)$ on their perception toward various ethical beliefs. Hence, $\mathrm{H} 1$ is supported.

Finally, the results show significant differences between The Religious Millennials and the other two segments (i.e. The Lukewarm Religious Millennials and the Least Religious Millennials) on Amorality and Distrust others. Hence, H2 is supported. The religious segment is less likely to disregard morality and less likely to distrust others (i.e. $\left.\mathrm{M}_{\text {AMORALITY }}=2.45 ; \mathrm{M}_{\text {DistRUSTOFOTHERS }}=2.76 ; p<0.05\right)$ compared to the Lukewarm Religious Millennials $\left(\mathrm{M}_{\text {AMORALITY }}=2.72 ; \mathrm{M}_{\text {Distrustofothers }}=2.98 ; p<0.05\right)$ and the Least Religious Millennials $\left(\mathrm{M}_{\text {AMORALITY }}=2.74 ; \mathrm{M}_{\text {DISTRUSTOFOTHERS }}=3.00 ; p<0.05\right)$. Furthermore, no significant differences were found on their desire to control between the three segments. Table 3 summarised each segment's profile based on consumer ethics and Machiavellianism. 


\section{DISCUSSION}

Berggren and Bjørnskov (2011) argue that religions such as Christianity, Judaism and Islam require their followers to adhere to ethical guidelines such as reciprocity and generosity towards others; i.e. "do unto others as they would do unto you". Although religious households and churches may apply strict behaviour codes, the benefits of religiosity and ethical behaviour for a person (i.e. Millennial), both physically and mentally, have been extensively acknowledged (e.g. Francis and Kaldor 2002; Gibson et al. 2008). Whilst studies have aimed to understand how consumers are differentiated based on psychographics (e.g. religiosity) (Azzi and Ehrenberg 1975; Gruber 2005; Tjiptono et al. 2017) and demographics (e.g. age) (Aaron et al. 2003; Alex-Assensoh and Assensoh 2001), this is the first known study to apply a posteriori multiple segmentation approach to profile consumers based on their differing religiosity, ethical beliefs (psychographics), prayer and church attendance (behavioural) and demographics (gender). In addition, as previously mentioned, this study complements other consumer ethics' studies using non-US culture (Ahmed et al. 2003; Rawwas et al. 2006; Singhapakdi et al. 2000, Siu et al. 2000) and extend other studies using an Indonesian sample (Arli and Tjiptono 2014).

The results of this study extend The Hunt-Vitell (2006) theory of ethics. It shows various environments (i.e. cultural, professional, industry, organisational) and personal characteristics create various segments. Consequently, these segments will perceive ethical problems, alternatives and consequences differently (see Hunt and Vitell 2006). This study has produced three segments. Most importantly, the Religious Millennials has the greatest religiosity (e.g. frequency of attending a worship service and praying) and also has the lowest levels of Machiavellianism beliefs. This segment can, therefore, be defined as the most sensitive to ethical issues. As a consequence, through segmentation, it can be concluded that religious consumers are more sensitive towards ethical issues, and less Machiavellian. 
Conversely, consumers (e.g. The Least Religious Millennials) that do not prescribe to religious behaviour may be less sensitive towards a potential ethical problem.

Whilst a plethora of studies have been conducted on younger cohorts within Westernised countries such as Britain (Abbotts et al. 2004; Francis and Kaldor 2002) and America (Ball et al. 2003; Durant et al. 1990), this study finds similarities to the literature within an Indonesian context. First, this study concluded that consumers (e.g. Millennials) that are more religious will exhibit greater agreement toward ethical behaviour (Ellison 1995; Jeong 2014).

For segmentation to be purposeful, researchers need to target segments that are not only measurable, but also substantial, accessible, and actionable (Kotler 1988). The results indicated that Millennials are varied on their perception towards various questionable behaviours. Furthermore, interest in religion may not recommence until a Millennial is in their elderly age or close to death (Halman 2006). Without this focus, the need for ethical behaviour may diminish, and consequently, more Machiavellianism behaviour may become evident in Indonesian Millennials. By also designing marketing strategies such as upholding prayer meetings on university campuses, church-orientated outreach events or bible studies, the Religious Millennials segment can also be encouraged about the importance and benefits of being religious and upholding ethical behaviour for themselves and the wider community.

The Least Religious Millennials represents a challenging segment. Unsurprisingly, this segment has the highest percentage of males which have been consistently acknowledged to attend church and pray less than females (e.g. Bruce 2006; Francis and Kaldor 2002). Whilst this segment is the least substantial (approximately a quarter of the sample) and may be unresponsive to religiosity and ethical behaviour (inapplicable), they still can be accessed whilst at university through carefully designed social marketing campaigns. Promoting the benefits of believing in God such as a deity that cares for them and their needs, improved 
self-esteem and health (e.g. psychological and mental) and the opportunity for an eternal afterlife, may sow a seed for the change that may become evident within the future. As religions (e.g. Christianity, Judaism) encourage their believers to witness and evangelise to their non-believing friends, family and colleagues (e.g. Barker and Carman 2009), highly religious, frequent church attending and praying Millennials (i.e. The Religious Millennials) should make it a priority to illustrate the importance and benefits of adhering to religion. Nonetheless, it is important to note that religion is not the only source of morality (Vitell 2009). Ethical beliefs can be influenced by ethical ideologies (idealism and relativism) (Forsyth and Berger 1982); materialism (Munch and Eastman 1988); personal and social norm (Wenzel 2004); and punishment (Workman and Gathegi 2006). 


\section{MANAGERIAL IMPLICATIONS}

The results of this study highlight the importance of segmentation in creating an appropriate strategy to understand consumers. By understanding differences between segments, each strategy can be tailored according to each segment.

Future studies involving consumers' religiosity need to include the intrinsic and extrinsic dimensions of individual consumers instead of just the intrinsic religiosity dimension. Cohen et al. (2005) suggest that intrinsic religiosity is related to the private aspect of religiosity while extrinsic religiosity is a community-related or social motivation for religions. Therefore, based on this study, a highly religious individual may not only exhibit high intrinsic religiosity (e.g. Allport and Ross 1967), but may also expect the external benefits of being a religious individual such as having likeminded friends or getting support from his/her religious community (Pekerti and Arli 2017).

Differences between segments may explain a contradicting fact in many religious societies, such as the prevalence of digital piracy in a religious society. High religiosity should be translated to less acceptance toward digital piracy. In this case, despite being considered as one of the most religious countries, Indonesia is considered as one the worst pirating nations in the world according to Business Software Alliance (BSA 2010). Software piracy remains constantly high in most religious nations such as Indonesia and Brazil. This gap might be due to differences in individuals' religiosity.

This study found that consumers who are highly religious are less likely to engage in various unethical behaviours. The results support previous studies, suggesting that religious people are more unlikely to engage in digital piracy behaviour compared to the less religious people (Casidy et al. 2016; Arli and Tjiptono, 2014; Arli and Pekerti 2016). However, the results of this study are in contrast with past studies that have found no link between religious ethical behaviour (Gerlich et al. 2010; Lewer et al. 2008; Parboteeah et al. 2008). 
Consequently, a combined effort of ethical education and stricter policies on unethical behaviour such as digital piracy, public littering are needed. For example, in the context of digital piracy, the Government needs to block illegal streaming websites simultaneously. Moreover, religious leaders need to collaborate with policy makers or social marketers to enhance religious teaching in primary and high schools in order to reduce unethical behaviour. A report indicated that Millennials are more likely to trust institution such as the church than their parents, which creates an opportunity for a religious institution to coach Millennials on the importance of ethics (Duffy, Shrimpton and Clemence 2017). Ethical teaching can be incorporated, with each religious teaching ensuring a clear understanding on how each unethical behaviour deviates from a religious teaching and should be avoided.

Finally, from the perspective of religious leaders, religious individuals are more likely to attend worship services and are more likely to pray. Hence, attending a worship service and praying should continuously be encouraged. The more these individuals attend a worship service and pray, the more likely these individual become religious and subsequently, the more ethical they are. Being lukewarm may not be too different with people who are the least religious, who often irregularly attend a worship service and pray. 


\section{LIMITATIONS}

This study has several limitations. First, this study was conducted in one major city and at one private university in Indonesia. Therefore, the results cannot be generalised across different contexts. The Millennials students in this study may come from wealthier families compared to the average Millennials in Indonesia. Future studies may collect data from other cities, islands and other income brackets which will give a complete picture of religious consumers in Indonesia. Second, this study did not segment and compare respondents based on religion (e.g. Muslim, Christianity, Catholic etc.) and between religious versus nonreligious consumers. There are differences between each religion which may influence their ethical beliefs. Longenecker et al. (2004) found that evangelical Christians showed a higher level of ethical judgment compared to other religions (i.e. Catholic, Protestant, Jewish, other religious and no religion). Future studies may investigate differences and similarities between faith categories/religion or denomination on their responses toward various ethical beliefs.

Third, another limitation of the study is that the number of female and male respondents are unequal (67\% female versus 33\% male). Studies have indicated that female are more ethically oriented than men (Shepard \& Hertenian 1991). Nonetheless, another study found that gender was not a significant determinant of consumer ethics (Vitell 2003). Hence, future research may investigate how females and males differ on their ethical beliefs and behaviour. Moreover, future study can explore the effect of religiosity and Machiavellians on consumer ethics. The results will be able to determine the effect of intrinsic, extrinsic personal and extrinsic social on consumer ethics. Finally, another limitation is the reliability score of 'Active' and 'No Harm' were below 0.70 (Hair 2006). Nonetheless, other studies have reported lower Alpha scores lower than 0.70. For example, Al-Khatib et al. (1995, 1997), Rawwas et al. (1994), and Polonski et al (2001) reported that 
the No Harm/No Foul construct had an Alpha of less than 0.50. Finally, future research can explore the effect of high and low Machiavellianism on religious consumers. Through experimentation, future studies may prime Machiavellianism and identify how much the manipulation effect consumers' perception toward ethical beliefs. ${ }^{2}$

\footnotetext{
${ }^{2}$ We thank an anonymous reviewer for this feedback.
} 
Ethical Approval: All procedures performed in studies involving human participants were in accordance with the ethical standards of the institutional and/or national research committee and with the 1964 Helsinki declaration and its later amendments or comparable ethical standards. 


\section{Reference}

Aaron, K. F., Levine, D., \& Burstin, H. R. (2003). African American Church Participation and Health Care Practices. Journal of General Internal Medicine, 18(11), 908-913.

Abbotts, J. E., Williams, R. G. A., Sweeting, H. N., \& West, P. B. (2004). Is going to church good or bad for you? Denomination, attendance and mental health of children in West Scotland. Social Science \& Medicine, 58(3), 645-666.

Ahmed, M., K. Y. Chung and J. W. Eichenseher (2003). Business Students Perception of Ethics and Moral Judgment: A Cross-Cultural Study', Journal of Business Ethics, 43(1/2), 89-102.

Al-Khatib, J. A., K. Dobie and S. J. Vitell (1995). Consumer Ethics In Developing Countries: An Empirical Investigation. Journal of Euro-Marketing 4(2), 87-110.

Al-Khatib, J., S. J. Vitell, and M. Y. A. Rawwas (1997). Consumer Ethics: A Cross-Cultural Investigation', European Journal of Marketing 31(11/12), 750-767

Al-Khatib, J. A., D'Auria Stanton, A., \& Rawwas, M. Y. (2005). Ethical segmentation of consumers in developing countries: A comparative analysis. International Marketing Review, 22(2), 225-246.

Al-Khatib, J. A., Robertson, C. J., \& Lascu, D. N. (2004). Post-communist consumer ethics: The case of Romania. Journal of Business Ethics, 54(1), 81-95.

Allport, G. W., \& Ross, J. M. (1967). Personal religious orientation and prejudice. Journal of Personality and Social Psychology, 5(4), 432-443.

American Psychiatric Association. (1994). Diagnostic and statistical manual of mental disorders (4th ed.). Washington, DC: Author.

Arli, D., Cherrier, H., \& Tjiptono, F. (2016). God blesses those who wear Prada: Exploring the impact of religiousness on attitudes toward luxury among the youth of Indonesia. Marketing Intelligence \& Planning, 34(1), 61-79.

Arli, D., Leo, C., \& Tjiptono, F. (2016). Investigating the impact of guilt and shame proneness on consumer ethics: a cross national study. International journal of consumer studies, 40(1), 2-13.

Arli, D., \& Pekerti, A. (2016). Investigating the influence of religion, ethical ideologies and generational cohorts toward consumer ethics: which one matters?. Social Responsibility Journal, 12(4), 770-785.

Arli, D., \& Tjiptono, F. (2014). The end of religion? Examining the role of religiousness, materialism, and long-term orientation on consumer ethics in Indonesia. Journal of Business Ethics, 123(3), 385-400. 
Arli, D., Tjiptono, F., Lasmono, H., \& Anandya, D. (2017). Do consumer ethics and consumer religiousness evolve across time? Insights from Millennials in Indonesia. Young Consumers, 18(4), 329-347.

Awad, T. A. (2011). Environmental segmentation alternatives: buyers' profiles and implications. Journal of Islamic Marketing, 2(1), 55-73.

Azzi, C., \& Ehrenberg, R. (1975). Household allocation of time and church attendance. The Journal of Political Economy, 83(1), 27-56.

Ball, J., Armistead, L., \& Austin, B.-j. (2003). The relationship between religiosity and adjustment among African-American, female, urban adolescents. Journal of Adolescence, 26(4), 431-446.

Barker, D. C., \& Carman, C. J. (2009). Political Geography, Church Attendance, and Mass Preferences Regarding Democratic Representation. Journal of Elections, Public Opinion and Parties, 19(2), 125-145.

Barnett, T., Bass, K., \& Brown, G. (1996). Religiosity, ethical ideology, and intentions to report a peer's wrongdoing. Journal of Business Ethics, 15(11), 1161-1174.

Berggren, N., \& Bjørnskov, C. (2011). Is the importance of religion in daily life related to social trust? Cross-country and cross-state comparisons. Journal of Economic Behavior \& Organization, 80(3), 459-480.

Bergman, J. Z., Westerman, J. W., Bergman, S. M., Westerman, J., \& Daly, J. P. (2013). Narcissism, materialism, and environmental ethics in business students. Journal of Management Education, 1052562913488108.

Bateman, C. R., \& Valentine, S. R. (2010). Investigating the effects of gender on consumers' moral philosophies and ethical intentions. Journal of Business Ethics, 95(3), 393-414.

Bjrkqvist, K., Lagerspetz, K. M., \& Kaukiainen, A. (1992). Do girls manipulate and boys fight? Developmental trends in regard to direct and indirect aggression. Aggressive Behavior, 18(2), 117-127.

Bonsu, S. K., \& Zwick, D. (2007). Exploring consumer ethics in Ghana, west Africa. International Journal of Consumer Studies, 31(6), 648-655.

Boslaugh, S. E., Kreuter, M. W., Nicholson, R. A., \& Naleid, K. (2005). Comparing demographic, health status and psychosocial strategies of audience segmentation to promote physical activity. Health Education Research, 20(4), 430-438.

Bowen, J. T. (1998). Market segmentation in hospitality research: no longer a sequential Process. International Journal of Contemporary Hospitality Management, 10(7), 289-296.

Brooks, A. C. (2006). Who really cares: America's charity divide. NY: Basic Books.

Brown, G. (2015). Millennials and Their \$1 Trillion Buying Power. Source:

http://www.totalyouthresearch.com/millennials-buying-power/. 
Brown, T. T. (2009). Rational praying: The economics of prayer. The Journal of SocioEconomics, 38(1), 37-44.

Bruce, D. A., Sterland, S. J. R., Brookes, N. E., \& Escott, P. (2006). An international study of congregations and worshipers: methodology and basic comparisons. Journal of Beliefs \& Values: Studies in Religion \& Education, 27(01), 3-12.

Bruwer, J., Saliba, A., \& Miller, B. (2011). Consumer behaviour and sensory preference differences: implications for wine product marketing. Journal of Consumer Marketing, 28(1), 5-18.

Bucic, T., Harris, J., \& Arli, D. (2012). Ethical consumers among the millennials: A crossnational study. Journal of Business Ethics, 110(1), 113-131.

Business Software Alliance (2010). 2010 Global PC Software Theft That Reaches Record \$59 Billion. Source: http://globalstudy.bsa.org/2010/.

Casidy, R., Phau, I., \& Lwin, M. (2016). Religiosity and Digital Piracy: An Empirical Examination. Services Marketing Quarterly, 37(1), 1-13.

CEIC (2013). Developing Indonesia's Youthful Population. Source:

$\mathrm{http}: / / \mathrm{www}$.ceicdata.com/en/blog/developing-indonesia\%E2\%80\%99s-youthful-population

Central Intelligence Agency (2015). The World Factbook: Indonesia. Source: https://www.cia.gov/library/publications/the-world-factbook/geos/id.html

Christie, R. \& Geis, F. L. (1970). Studies in Machiavellianism. New York: Academic Press.

Cohen, A. B., Pierce, J. D., Chambers, J., Meade, R., Gorvine, B. J., \& Koenig, H. G. (2005). Intrinsic and extrinsic religiosity, belief in the afterlife, death anxiety, and life satisfaction in young Catholics and Protestants. Journal of Research in Personality, 39(3), 307-324.

Collins, D. (2000). The quest to improve the human condition: The first 1,500 articles published in the "Journal of Business Ethics". Journal of Business Ethics, 26(1), 1-73.

Connell, J. (2005). Hillsong: A Megachurch in the Sydney Suburbs. Australian Geographer, $36(3), 315-332$.

Crabtree, S. (2010). Religiosity Highest in World's Poorest Nations. Source: http://www.gallup.com/poll/142727/religiosity-highest-world-poorest-nations.aspx.

Culiberg, B., \& Mihelič, K. K. (2016). Three ethical frames of reference: insights into Millennials' ethical judgements and intentions in the workplace. Business Ethics: A European Review, 25(1), 94-111.

Dahling, J. J., Whitaker, B. G., \& Levy, P. E. (2008). The development and validation of a new Machiavellianismism scale. Journal of Management, 35(2), 219-257. 
Dansirichaisawat, R., \& Suwunnamek, O. (2014). Discovering Environmental Attitude and Lifestyle Segmentation of Green Consumers: a Conceptual Model for Research. Journal of Social and Development Sciences, 5(2), 102-110.

Delener, N. (1990). The effects of religious factors on perceived risk in durable goods purchase decisions. Journal of Consumer Marketing, 7(3), 27-38.

Delloitte (2014). The Millennial Survey 2014. Source:

http://www2.deloitte.com/al/en/pages/about-deloitte/articles/2014-millennial-survey-positiveimpact.html.

Diamandis, P. (2015). Why the Millennials are the most important generation yet. Source: http://singularityhub.com/2015/06/02/millennials-important-generation-yet/

Dickson, P. R., \& Ginter, J. L. (1987). Market segmentation, product differentiation, and marketing strategy. The Journal of Marketing, 51(2), 1-10.

Dietrich, T., Rundle-Thiele, S., Schuster, L., Drennan, J., Russell-Bennett, R., Leo, C., ... \& Connor, J. P. (2015). Differential segmentation responses to an alcohol social marketing program. Addictive Behaviors, 49 (October), 68-77.

Dolnicar, S. (2004). Beyond 'Commonsense Segmentation: A Systematics of Segmentation Approaches in Tourism. Journal of Travel Research, 42(3), 244-250.

Donovan, R. J., Egger, G., \& Francas, M. (1999). TARPARE: a method for selecting target audiences for public health interventions. Australian and New Zealand Journal of Public Health, 23(3), 280-284.

Duffy, B., Shrimpton, H. and Clemence, M. (2017). Millenials: Myth and Realities. Source: https://www.ipsos.com/sites/default/files/2017-05/ipsos-mori-millennial-myths-realitiessummary-report.pdf.

Durant, R. H., Seymore, C., Pendergrast, R., \& Beckman, R. (1990). Contraceptive Behavior among Sexually Active Hispanic Adolescents. Journal of Adolescent Health, 11(6), 490-496.

Eister, A. W. (1964). Perspective on the functions of religion in a developing country: Islam in Pakistan. Journal for the Scientific Study of Religion, 3(2), 227-238.

Ellison, C. G. (1995). Race, religious involvement and depressive symptomatology in a Southeastern U.S. community. Social Science \& Medicine, 40(11), 1561-1572.

Farris, R., Chong, F. and Dunning, D. (2002). Generation Y: purchasing power and implications for marketing". Academy of Marketing Studies Journal, 6(2), 89-101.

Farwell, L., \& Wohlwend-Lloyd, R. (1998). Narcissistic processes: Optimistic expectations, favorable self-evaluations, and self-enhancing attributions. Journal of Personality, 66(1), 6583.

Flurry, L. A., \& Swimberghe, K. (2016). Consumer ethics of adolescents. Journal of Marketing Theory and Practice, 24(1), 91-108. 
Ford, J. M. (2006). Some Implications of Denominational Heterogeneity and Church Attendance for Alcohol Consumption Among Hispanics. Journal for the Scientific Study of Religion, 45(2), 253-267.

Forsyth, D. R., \& Berger, R. E. (1982). The effects of ethical ideology on moral behavior. The Journal of Social Psychology, 117(1), 53-56.

Francis, L. J. \& Kaldor, P. (2002). The Relationship Between Psychological Well-Being and Christian Faith and Practice in an Australian Population Sample. Journal for the Scientific Study of Religion, 41(1), 179-184.

Francis, L. J., Robbins, M., Lewis, C. A., Quigley, C. F. \& C, W. (2004). Religiosity and general health among undergraduate students: a response to O'Connor, Cobb, and O'Connor (2003). Personality and Individual Differences, 37(3), 485-494.

Gerlich, R. N., Lewer, J. J., \& Lucas, D. (2010). Illegal media file sharing: The impact of cultural and demographic factors. Journal of Internet Commerce, 9(2), 104-126.

Gibson, T. (2008). Religion and civic engagement among America's youth. The Social Science Journal, 45(3), 504-514.

Grabrini, C. (2016). Understanding Generational Differences: Millenials' View of Ethics. Source: http://patimes.org/understanding-generational-differences-millennials-view-ethics/

Green, R. M. (1988). Religion and moral reason: A new method for comparative study. Oxford, Oxford University Press.

Gruber, J. H. (2005). Religious Market Structure, Religious Participation, and Outcomes: Is Religion Good for You? Advances in Economic Analysis \& Policy, 5(1), 1-30.

Hair, Jr.,J.F., Anderson. R.E., Tatham, R.L. \& Black, W.C, ( 2006). Multivariate data Analysis. Upper Saddle River, New Jersey: Prentice Hall.

Halman, L., \& Draulans, V. (2006). How secular in Europe? The British Journal of Sociology, 57(2), 263-288.

Henington, C., Hughes, J. N., Cavell, T. A., \& Thompson, B. (1999). The role of relational aggression in identifying aggressive boys and girls. Journal of School Psychology, 36(4), 457-477.

Hirschle, J. (2010). From Religious to Consumption-Related Routine Activities? Analyzing Ireland's Economic Boom and the Decline in Church Attendance. Journal for the Scientific Study of Religion, 49(4), 673-687.

Hodge, A. and Rayda, N. (2018). Indonesia's rising tide of intolerance. Source: https://www.theaustralian.com.au/news/inquirer/indonesias-rising-tide-of-intolerance/newsstory/7a85e8db9e3578291a3a1fc59adb77a7.

Howe, N., \& Strauss, W. (2009). Millennials rising: The next great generation. Vintage. 
Huelsman, M. A., Piroch, J. \& Wasieleski, D. (2006). Relation of religiosity with academic dishonesty in a sample of college students. Psychological Report, 99(3), 739-742.

Hunt, S. D. (1990). Commentary on an empirical investigation of a general theory of marketing ethics. Journal of the Academy of Marketing Science, 18(2), 173-7.

Hunt, S. D., \& Chonko, L. B. (1984). Marketing and Machiavellianism. The Journal of Marketing, 48(3), 30-42.

Hunt, S. D., \& Vitell, S. (1986). A general theory of marketing ethics. Journal of Macromarketing, 6(1), 5-16.

Hunt, S. D., \& Vitell, S. J. (2006). The general theory of marketing ethics: A revision and three questions. Journal of Macromarketing, 26(2), 143-153.

Iannaccone, L. R. (1992). Sacrifice and stigma: reducing free-riding in cults, communes, and other collectives, Journal of Political Economy, 100(2), 271-291.

Jakarta Post (2017). Editorial: Xenophobic millenials. Source: http://www.thejakartapost.com/academia/2017/11/06/editorial-xenophobic-millennials.html.

Jeong, H. O. (2014). Religious involvement and group identification: The case of Hispanics in the United States. The Social Sciences Journal, 51(1), 21-29.

Jones, G. E. \& Kavanagh, M. J. (1996). An experimental examination of the effects of individual and situational factors on unethical behavioral intentions in the workplace. Journal of Business Ethics, 15(5), 511-523.

Kernis, M. H., \& Sun, C. (1994). Narcissism and reactions to interpersonal feedback. Journal of Research in Personality, 28(1), 4-13.

Kirkpatrick, L. A. (1989). A psychometric analysis of the Allport-Ross and Feagin measures of intrinsic-extrinsic religious orientation. Research in the social scientific study of religion, 1, 1-31.

Koenig, H. G., Ford, S. M., George, L. K., Blazer, D. G., \& Meador, K. G. (1993). Religion and Anxiety Disorder: An Examination and Comparison of Associations in Young, MiddleAged, and Elderly Adults. Journal of Anxiety Disorders, 7(4), 321-342.

Kolb, B. M. (2006), Tourism Marketing for Cities and Towns- Using Branding and Events to Attract Tourists. Amsterdam, Holland: Elsevier/Butterworth-Heinemann.

Kotler, P. (1988). Marketing Management: Analysis, Planning, Implementation, and Control. Englewood Cliffs, NJ: Prentice Hall.

Lance, C. E., Butts, M. M., \& Michels, L.C. (2006). The sources of four commonly reported cutoff criteria: What did they really say? Organizational Research Methods, 9(2), 202-220. 
Lewer, J. J., Gerlich, R. N., \& Lucas, D. (2008). The Impact of Christian Education and Curriculum on Illegal Media File Sharing Attitudes and Behavior. Christian Business Academy Review, 3 (Spring), 70-79.

Longenecker, J. G., McKinney, J. A., \& Moore, C. W. (2004). Religious intensity, evangelical Christianity, and business ethics: An empirical study. Journal of Business Ethics, 55(4), 371-384.

Lu, L. C., \& Lu, C. J. (2010). Moral philosophy, materialism, and consumer ethics: An exploratory study in Indonesia. Journal of Business Ethics, 94(2), 193-210.

MacIlvaine, W. R., Nelson, L. A., Stewart, J. A., \& Stewart, W. C. (2013). Association of strength of religious adherance to quality of life measures. Complementary Therapies in Clinical Practice, 19(4), 251-255.

March, R. \& Woodside, A. G. (2005). Tourism Behaviour: Travellers' Decisions and Actions. Wallingford, UK: CABI Publishing, CAB International.

McBeth, J. (2018). A youthful intolerance takes hold in Indonesia. Source: http://www.atimes.com/article/a-youthful-intolerance-takes-hold-in-indonesia/

McDaniel, S. W., \& Burnett, J. J. (1990). Consumer religiosity and retail store evaluative criteria. Journal of the Academy of Marketing Science, 18(2), 101-112.

McGlone, T., Spain, J. W., \& McGlone, V. (2011). Corporate social responsibility and the millennials. Journal of Education for Business, 86(4), 195-200.

McNichols, C. W., \& Zimmerer, T. W. (1985). Situational ethics: An empirical study of differentiators of student attitudes. Journal of Business Ethics, 4(3), 175-180.

Murphy, P. E. \& Murphy, A. E. (2004). Strategic management for tourism communities: bridging the gaps. Clevedon, Buffalo: Channel View Publications.

Muncy, J. A., \& Eastman, J. K. (1998). Materialism and consumer ethics: An exploratory study. Journal of Business Ethics, 17(2), 137-145.

Muncy, J. A., \& Vitell, S. J. (1992). Consumer ethics: An investigation of the ethical beliefs of the final consumer. Journal of Business Research, 24(4), 297-311.

Nelson, M. F., James, M. S., Miles, A., Morrell, D. L., \& Sledge, S. (2017). Academic Integrity of Millennials: The impact of religion and Spirituality. Ethics \& Behavior, 27(5), $385-400$.

Norušis, M. (2011). Chapter 17 - Cluster Analysis. In IBM SPSS Statistics Guides (pp. 375404). Addison Wesley.

Paciotti, B., Richerson, P., Baum, B., Lubell, M., Waring, T., McElreath, R., ... \& Edsten, E. (2011). Are religious individuals more generous, trusting, and cooperative? An experimental test of the effect of religion on prosociality. In The economics of religion: Anthropological approaches (pp. 267-305). Emerald Group Publishing Limited. 
Parboteeah, K. P., Hoegl, M., \& Cullen, J. B. (2008). Ethics and religion: An empirical test of a multidimensional model. Journal of Business Ethics, 80(2), 387-398.

Park, D. B., \& Yoon, Y. S. (2009). Segmentation by motivation in rural tourism: A Korean case study. Tourism Management, 30(1), 99-108.

Pekerti, A. A., \& Arli, D. (2017). Do cultural and generational cohorts matter to ideologies and consumer ethics? A comparative study of Australians, Indonesians, and Indonesian migrants in Australia. Journal of Business Ethics, 143(2), 387-404.

Pendergast, D. (2007). 'The MilGen and Society', in Being a Millennial Adolescent: What Do Teachers Need to Know?, eds. N. Bahr and D. Pendergast (Camberwell: Australian Council for Educational Research), http://shop.acer.edu.au/acershop/product/0864316933.

Perret, J. \& Holmlund, M. (2013). Ethics and responsibility in relationship marketing. Marketing Intelligence and Planning, 31(7), 746-763.

Phillips, C. (2007). The Millennial handbook: A snapshot guide to everything Gen Y. South Bend, IN: Brand Amplitude.

Polonsky, M. J., Brito, P. Q., Pinto, J., \& Higgs-Kleyn, N. (2001). Consumer ethics in the European Union: A comparison of northern and southern views. Journal of Business Ethics, 31(2), 117-130.

Punj, G., \& Stewart, D. W. (1983). Cluster analysis in marketing research: Review and suggestions for application. Journal of Marketing Research, 20(2), 134-148.

Rallapalli, K. C., Vitell, S. J., Wiebe, F. A., \& Barnes, J. H. (1994). Consumer ethical beliefs and personality traits: An exploratory analysis. Journal of Business Ethics, 13(7), 487-495.

Randolph-Seng, B. \& Nielsen, M. E. (2007). Honesty: One effect of primed religious representations. International Journal for the Psychology of Religion, 17(4), 303-315

Rawwas, M. Y. A., Vitell, S. J. \& Al Khatib, J. A. (1994). Consumer Ethics: The Possible Effects of Terrorism and Civil Unrest on the Ethical Values of Consumers. Journal of Business Ethics, 13(3), 223-231.

Rawwas, M. Y. A., Swaidan, Z. \& Al-Khatib, J. A. (2006). Does religion Matter? A Comparison Study of the Ethical Beliefs of Marketing Students of Religious and Secular Universities in Japan. Journal of Business Ethics 65(1), 69-86

Ross, W. T., \& Robertson, D. C. (2003). A typology of situational factors: Impact on salesperson decision-making about ethical issues. Journal of Business Ethics, 46, 213-234.

Sarahtika, D and Yasmine, D. (2018). Millennials put Muslim lifestyle of display. Source: http://insight.jakartaglobe.id/millennials-put-muslim-lifestyle-on-display/ 
Schawbel, D. (2013). Why you can't ignore Millennials. Source:

http://www.forbes.com/sites/danschawbel/2013/09/04/why-you-cant-ignoremillennials/\#4b7525486c65.

Schuster, L., Kubacki, K., \& Rundle-Thiele, S. (2015). A theoretical approach to segmenting children's walking behaviour. Young Consumers, 16(2), 159-171.

Shepard, J. M., \& Hartenian, L. S. (1991). Egoistic and ethical orientations of university students toward work-related decisions. Journal of Business Ethics, 10(4), 303-310.

Shoemaker, S. (1989). Segmentation of the senior pleasure travel market. Journal of Travel Research, 27(3), 14-21.

Singhapakdi, A., Salyachivin, S, Virakul, B., \& Veerayangkur, V. (2000). Some Important Factors Underlying Ethical Decision Making of Managers in Thailand. Journal of Business Ethics 27(3), 271-284.

Singhapakdi, A., \& Vitell, S. J. (1990). Marketing ethics: Factors influencing perceptions of ethical problems and alternatives. Journal of Macromarketing 10 (Spring), 4-18.

Siu, N. Y. M, Dickinson, J. R. \& Lee, B. Y. Y. (2000). Ethical Evaluations of Business Activities and Personal Religiousness. Teaching Business Ethics, 4(3), 233-256.

Straughan, R. D., \& Roberts, J. A. (1999). Environmental segmentation alternatives: a look at green consumer behavior in the new millennium. Journal of Consumer Marketing, 16(6), 558-575.

Swaidan, Z. (2012). Culture and consumer ethics. Journal of Business Ethics, 108(2), 201213.

Tang, T. L. P., \& Tang, T. L. N. (2010). Finding the lost sheep: A panel study of business students' intrinsic religiosity, Machiavellianismism, and unethical behavior intentions. Ethics \& Behavior, 20(5), 352-379.

Tjiptono, F., Arli, D., \& Winit, W. (2017). Gender and young consumer ethics: an examination in two Southeast Asian countries. Young Consumers, 18(1), 94-114.

Tkaczynski, A., \& Rundle-Thiele, S. (2013). Understanding what really motivates attendance: A music festival segmentation study. Journal of Travel \& Tourism Marketing, 30(6), 610-623.

Tkaczynski, A., Rundle-Thiele, S. R., \& Prebensen, N. K. (2015). Segmenting Potential Nature-Based Tourists Based on Temporal Factors The Case of Norway. Journal of Travel Research, 54(2), 251-265.

Twenge, J. M., Konrath, S., Foster, J. D., Keith Campbell, W., \& Bushman, B. J. (2008). Egos inflating over time: A cross-temporal meta-analysis of the Narcissistic Personality Inventory. Journal of Personality, 76(4), 875-902. 
Varkey Foundation (2018). Generation Z: Global Citizenship Survey. Source:

https://www.varkeyfoundation.org/what-we-do/policy-research/generation-z-global-

citizenship-survey/

Varagur, K. (2017). Indonesia's moderate Islam is slowly crumbling. Source:

https://foreignpolicy.com/2017/02/14/indonesias-moderate-islam-is-slowly-crumbling/.

Vitell, S. J. (2003). Consumer ethics research: Review, synthesis and suggestions for the future. Journal of Business Ethics, 43(1-2), 33-47.

Vitell, S. J. (2009). The role of religiosity in business and consumer ethics: A review of the literature. Journal of Business Ethics, 90(2), 155-167.

Vitell, S. J., \& Hunt, S. D. (1990). The general theory of marketing ethics: A partial test of the model. In Research in Marketing Vol 10, (pp. 237-265), Greenwich, CT: JAI.

Vitell, S. J., \& Muncy, J. (1992). Consumer ethics: An empirical investigation of factors influencing ethical judgments of the final consumer. Journal of Business Ethics, 11(8), 585597.

Vitell, S. J., \& Muncy, J. (2005). The Muncy-Vitell consumer ethics scale: A modification and application. Journal of Business Ethics, 62(3), 267-275.

Vitell, S. J., King, R. A., Howie, K., Toti, J. F., Albert, L., Hidalgo, E. R., \& Yacout, O. (2016). Spirituality, moral identity, and consumer ethics: A multi-cultural study. Journal of Business Ethics, 139(1), 147-160.

Vitell, S. J. \& Paolillo, G. P. (2003). Consumer ethics: The role of religiosity. Journal of Business Ethics, 46(2), 151-162.

Vitell, S. J., Paolillo, J. G. P. \& Singh, J. J. (2005). Religiosity and consumer ethics. Journal of Business Ethics, 57(2), 175-181.

Vitell, S. J., Paolillo, J. G., \& Singh, J. J. (2006). The role of money and religiosity in determining consumers' ethical beliefs. Journal of Business Ethics, 64(2), 117-124.

Vitell, S. J., Lumpkin, J. R., \& Rawwas, M. Y. (2013). Consumer Ethics: An Investigation of the Ethical Beliefs of Elderly Consumers. In Citation Classics from the Journal of Business Ethics (pp. 447-461). Netherlands, Springer.

Vitell, S. J., Paolillo, J. G. P. and Singh, J. J. (2006). The role of money and religiosity in determining consumers' ethical beliefs. Journal of Business Ethics, 64 (2), 117-124.

Vitell, S. J., Singhapakdi, A., \& Thomas, J. (2001). Consumer ethics: an application and empirical testing of the Hunt-Vitell theory of ethics. Journal of Consumer Marketing, 18(2), 153-178.

Weber, J. (2017). Understanding the Millennials' Integrated Ethical Decision-Making Process: Assessing the Relationship Between Personal Values and Cognitive Moral Reasoning. Business \& Society, 0007650317726985. 
Wenzel, M. (2004). The social side of sanctions: Personal and social norms as moderators of deterrence. Law and Human Behavior, 28(5), 547-567.

Westerman, J. W., Bergman, J. Z., Bergman, S. M., \& Daly, J. P. (2011). Are universities creating millennial narcissistic employees? An empirical examination of narcissism in business students and its implications. Journal of Management Education, 1052562911408097.

Wilkes, R. E., Burnett, J. J., \& Howell, R. D. (1986). On the meaning and measurement of religiosity in consumer research. Journal of the Academy of Marketing Science, 14(1), 47-56.

Workman, M., \& Gathegi, J. (2007). Punishment and ethics deterrents: A study of insider security contravention. Journal of the American Society for Information Science and Technology, 58(2), 212-222.

World Atlas (2016). Most Religious Countries In The World. Source: http://www.worldatlas.com/articles/most-religious-countries-in-the-world.html

Yilmaz, O., \& Bahçekapili, H. G. (2015). Without God, everything is permitted? The reciprocal influence of religious and meta-ethical beliefs. Journal of Experimental Social Psychology, 58(May), 95-100. 
